\title{
Introduction : Perspectives on legume production and use in European agriculture
}

\section{Watson, Christine A.}

CABI

2017-05

Watson, C A \& Stoddard , F L 2017 , Introduction : Perspectives on legume production and use in European agriculture . in D Murphy-Bokern, F L Stoddard \& C A Watson (eds), Legumes in Cropping Systems . CABI , Wallingford , pp. 1-17 . https://doi.org/10.1079/9781780644981.0001

http://hdl.handle.net/10138/300032

https://doi.org/10.1079/9781780644981.0001

cc_by

publishedVersion

Downloaded from Helda, University of Helsinki institutional repository.

This is an electronic reprint of the original article.

This reprint may differ from the original in pagination and typographic detail.

Please cite the original version. 


\title{
Introduction - Perspectives on Legume Production and Use in European Agriculture
}

\author{
Christine A. Watson ${ }^{1 *}$ and Frederick L. Stoddard ${ }^{2}$ \\ ${ }^{1}$ Scotland's Rural College, Edinburgh, UK; ${ }^{2}$ University of Helsinki, \\ Helsinki, Finland
}

\begin{abstract}
Grain legumes currently cover less than $2 \%$ of European arable area, and estimates of forage legume coverage are little greater. Imported legume protein, however, is an important livestock feed additive. This chapter introduces the varied roles of legumes in cropping systems and in food and feed value chains.
\end{abstract}

\section{Introduction: Importance of Legumes in European Union (EU) Agriculture}

Grain and forage legumes play an important role in European agriculture by providing protein-rich food and feed. However, Europe currently depends on importing large quantities of high-protein crop produce ( 15 million $t$ of soybean and 25 million $t$ of soy meal in 2013 (Eurostat, 2016)) mainly from South America to meet demand for feed for pigs and poultry. This accounted for about $12 \%$ of the worldwide production of soybean in 2013/14, and 15 million ha of arable land outside the EU (Westhoek et al., 2011). In 2013, grain legumes were produced on 1.8 million ha of land in Europe (1.6\% of the arable area) compared with 5.8 million ha in 1961 (4.7\%). On average over the 1961-2011 period, Europe imported $63 \%$ of its domestic supply of grain legumes (Cernay et al., 2015, based on FAOSTAT, 2015). Forage is produced on permanent grasslands (pastures), on temporary grassland rotated with arable crops also known as leys, and by dedicated forage legume crops such as lucerne (alfalfa). The area of pasture containing forage legumes, and the proportion of legume in the pasture, is not recorded in all EU countries, making it difficult to estimate their overall contribution. However, estimates from CAPRI, the Common Agricultural Policy Regional Impact modelling

*christine.watson@sruc.ac.uk 
system (http://www.capri-model.org/dokuwiki/doku.php accessed 30 September 2016), suggest that forage legumes play a minor role, covering an average of $3-10 \%$ in grassland mixtures in each country (Baddeley et al., 2013), while Eurostat showed pure stands of lucerne and clover on 2.1 million ha in 2009.

The per capita consumption of livestock products continues to increase worldwide (Lassaletta et al., 2014). In Europe, there has been a fourfold increase in poultry meat consumption over the last 50 years, with pig meat consumption increasing by $80 \%$ over the same period (Westhoek et al., 2011). The increased consumption of products from monogastric animals has driven changes in the use of crop land and crop products to supply the demand for livestock feed (Pelletier and Tyedmers, 2010) and the increased availability of inexpensive feed has allowed the monogastric sector to grow. This intensification of agriculture has resulted in a shift from pasture-based systems to indoor rearing, influencing the amount of concentrate feed used in livestock production (Hasha, 2002). In Europe, crises in farming such as concerns over animal proteins in livestock diets in the 1990s (bovine spongiform encephalopathy (BSE)) have also changed livestock diets, contributing to the further increase in the use of soybean in livestock diets (Vicenti et al., 2009).

Increasing home-grown production of legumes is attractive because it contributes to the sustainable development of European agriculture by a variety of mechanisms, including reduced dependence on fossil fuels in agriculture, reduced greenhouse gas (GHG) emissions, increased crop diversity in cropping systems, increases in above and below ground biodiversity, improved soil fertility, increased carbon storage, and reconnection of crop and livestock production. Perhaps the most distinctive and valuable feature of legumes is their capacity for biological nitrogen fixation (BNF) in symbiosis with bacteria in the Rhizobiaceae. This book explores some agronomic and environmental aspects of the current production of forage and grain legumes in Europe. We exclude leguminous trees such as carob because of their minor economic role, although they have value as feed, food and fuel resources.

\section{Producing Legumes}

\section{Grain production systems}

Grain legumes are produced in a variety of ways across Europe, including as dry grain, green forage, arable silage and green manure, with the choice often depending on climatic and edaphic conditions as well as intended end-use. Several species are grown in Europe, some with both spring-sown and autumn-sown variants. The main species are pea (Pisum sativum L.), lupins (Lupinus spp.), faba bean (Vicia faba L.), chickpea (Cicer arietinum L.), lentil (Lens culinaris Medik.), common bean (Phaseolus vulgaris L.) and soybean (Glycine max (L.) Merr.). Although soybean is officially classified by the Food and Agriculture Organization of the United Nations (FAO) as an oilseed crop rather than a protein crop, it has a similar function in cropping systems to the other grain legumes and is the reference protein crop, so we include it here. Grain legumes are most commonly produced as sole 
crops, although there is currently great interest in intercropping (Malézieux et al., 2009). Cereal/legume intercrops can be grown for grain or silage, the latter as a way of boosting the forage protein content of livestock diets (Anil et al., 1998) mainly under wetter conditions in northern and western Europe, and in some situations have a higher and more stable gross margin than the mean of the sole crops (Bedoussac et al., 2015).

\section{Forage production systems}

Forage is produced on permanent grasslands (pastures), on temporary grassland rotated with arable crops also known as leys, and by dedicated forage legume crops such as lucerne (Medicago sativa L.). Although forage legumes are grown in an estimated 2.1 million ha as pure stands (Eurostat data for 2009), they are more generally grown in mixtures with grasses, other legumes and forbs. They are attractive because: (i) they allow reduction or elimination of nitrogen (N) fertilizer use; and (ii) they benefit the farming system by supplying $\mathrm{N}$ to following crops, and improving soil structure and biodiversity. Grass-legume mixtures provide significant agronomic benefits in terms of yield, agronomic quality, low input costs, and feed quality as compared with pure grass and (sometimes) silage maize (Peyraud et al., 2009). Disadvantages include slow growth in spring (Peyraud et al., 2009), less persistence than grass under grazing, risk of livestock bloat and some difficulties in conservation as hay or silage (Phelan et al., 2015). They are also used in some medium intensity systems to reduce the need for fertilizer N (e.g. organic grasslands). The use of fertilizer reduces clover content of mixtures below $50 \%$ (Carlsson and Huss-Danell, 2003) and the combination of high fertilizer use and stocking rates practically eliminates the legume component (clover) and its impact (O'Mara, 2008).

Red clover (Trifolium pratense L.) leys generally last 2-3 years, whereas white clover (Trifolium repens L.) stands can last 15 years or more (Humphreys et al., 2008; Stoddard et al., 2009). White clover is the subject of Chapter 9, this volume, and red clover of Chapter 10, where their management is discussed in detail.

\section{Nutrition - Humans and Livestock}

Grain legumes are important in the human diet in providing protein, essential amino acids and nutrients through direct consumption and indirectly through meat, fish, milk and eggs. Current nutritional guides such as The Eatwell Guide in the UK (Public Health England, 2016) and the Finnish National Nutrition Council (VRN, 2014) suggest decreased consumption of animal protein and increased use of vegetable protein, particularly from food legumes. Grain legume seeds contain protein, energy in the form of starch or oil, dietary fibre, micro- and macronutrients, vitamins and numerous bioactive phytochemicals (Strohle et al., 2006), such as flavonoids and other antioxidants (Scalbert et al., 2005). They provide dietary iron, zinc and calcium, all of which are important for humans and monogastric animals, but the availability of these nutrients is reduced by chelation 
to inositol hexakisphosphate (phytate). There is increasing interest in the use of preparation procedures such as germination and fermentation to enhance both macro and trace element availability (Humer and Schedle, 2016). The protein content of grain legume species ranges from $20 \%$ in common bean and lentil to $40 \%$ in soybean and yellow lupin (see Chapter 5, this volume). This compares with $7-17 \%$ in cereals and $17-26 \%$ in rapeseed (Day, 2013). There are significant positive effects on human health when animal proteins are replaced by plant protein including lowering cholesterol (Harland and Haffner, 2008), controlling hypertension (Harland and Haffner, 2008) and improving cardiovascular health (Sirtori et al., 2009). Eating soybean and lupin can decrease cholesterol in humans (Sirtori et al., 2012), and grain legumes may also be useful in the diet of diabetics (Bertoglio et al., 2011) and in maintaining a healthy weight (McCrory et al., 2010). A role in prevention of some cancers has also been suggested (CamposVega et al., 2010). There is a large body of research on the health benefits of pulses (the starchy grain legumes), including a special issue of the British Journal of Nutrition in 2012 (volume 108, Supplement S1).

In addition to their high protein content, forage legumes have the advantage of high voluntary intake and animal production when feed supply is nonlimiting (Phelan et al., 2015). A literature review (Steinshamn, 2010) showed that red clover and white clover increased dry matter intake by $1.2 \mathrm{~kg}$ and $1.3 \mathrm{~kg}$, respectively, relative to grass-based diets and that milk yield was $1.5 \mathrm{~kg} /$ day and $2.2 \mathrm{~kg} /$ day higher, respectively. Condensed tannins present in forage legumes can benefit ruminant animal health, by reducing the risk of bloat and the parasitic worm burden (Waghorn, 2008) as well as potentially reducing GHG emissions (Beauchemin et al., 2008; Azunhwi et al., 2013). The consumer can also benefit from the impacts of bioactive compounds present in legumes such as condensed tannins and polyphenols through both improved meat flavour (Schreurs et al., 2007) and increased levels of beneficial fatty acids (Girard et al., 2015).

Legumes have the potential to replace part or all of the fish meal in the diets of farmed fish and the potential of a range of plant-based protein sources was recently reviewed by Ayadi et al. (2012). Grain legumes are a suitable feed for herbivorous fish such as carp (Cyprinus carpio), but a variety of legume-based extrudates can substitute for the fish meal normally used for many farmed carnivorous fish and crustaceans (Trushenski et al., 2006). Soybean, particularly in high doses, can reduce growth rate due, at least in part, to antinutritional components (Kroghdahl et al., 2010), but work is underway to breed new lines of soybean specifically for aquaculture (Herman and Schmidt, 2016). Compounded fish feeds contained a mean of $25 \%$ soybean meal in 2008 , representing $4.5 \%$ of world soybean meal production in that year, and a trend was detected for increased use of other pulse and cereal proteins (Tacon et al., 2011). There are numerous studies in the literature focusing on determining the best grain legume protein, and its optimal proportion in the diet, for different fish. For example, rainbow trout grew well on up to $30 \%$ narrow-leafed lupin meal (Glencross et al., 2008). Faba bean or pea flour can replace some of the wheat or other cereal starch in the formulation of feed pellets under heat extrusion. Blending of different protein sources into a mixture is also common, as it balances the amino acid composition and dilutes the 
antinutritional effects of individual components (Gomes et al., 1995). These aspects were reviewed in a Legume Futures report on novel feed and non-food uses of legumes (Stoddard, 2013).

The FAO (2004) estimated that soybean meal accounted for $75 \%$ of the high-protein raw materials used in compounded livestock feeds. The amount of soy required per kilogram of product ranges from $11 \mathrm{~g} / \mathrm{kg}$ for raw milk through $330 \mathrm{~g} / \mathrm{kg}$ for eggs to $600 \mathrm{~g} / \mathrm{kg}$ for poultry meat (Hoste and Bolhuis, 2010).

Legumes protect themselves from oxidative stresses and herbivores with a range of secondary compounds, including alkaloids, saponins and isoflavonoids that often have so-called antinutritional effects. The presence of these antinutritional factors substantially limits the use of legumes in monogastric diets, sometimes through reducing nutrient digestibility and absorption (Gatel, 1994), sometimes affecting feed intake and nutrient digestibilities, and sometimes, such as vicine-convicine to chickens, toxicity (e.g. Huisman and Jansman, 1991). These antinutritional factors include non-starch polysaccharides (NSP), tannins, alkaloids, pyrimidine glycosides, lectins and trypsin inhibitors (TIs), depending on the species (see Chapter 5, this volume). Soybean meal (SBM) is the main protein supplement in pig feed (Crépon 2006; Jezierny et al., 2010) due to its high crude protein (CP) content (44\%) and useful amino acid profile, but its powerful TIs require denaturing. The rising costs of soybean meal and the environmental controversy over soybean imports has given rise to increased interest in the use of alternative home-produced legumes. Other grain legumes contain considerably less protein and quite different amino acid profiles, with methionine and tryptophan being the usual limiting amino acids. White et al. (2015) recently demonstrated the viability of alternative grower and finisher pig diets formulated from pea and faba bean. Pea, low-vicine faba bean and lupins all work as partial substitutes for soybean in broiler diets, with pea generally performing best (Diaz et al., 2006; Palander et al., 2006). These alternatives to soybean have also been shown to be acceptable in egg production (Laudadio and Tufarelli, 2010). Soybean in ruminant rations can also be partially replaced by pea, faba bean and lupins (Vander Pol et al., 2008; Volpelli et al., 2010; Dawson, 2012). This can potentially affect both yield and product quality (Renna et al., 2012).

Some secondary compounds have medicinal uses. Two well-known drugs derived from products of forage legumes are the antithrombotic warfarin, which comes from sweet clover's coumarin, and the antidiabetic metformin, derived from sainfoin's guanidine. In some cases, analysis has not proceeded beyond a crude aqueous or solvent extract, but in many cases the specific active compound has been identified and tested. Cornara et al. (2015) recently reviewed temperate forage legumes as a resource for nutraceuticals and pharmaceuticals.

\section{Non-food Uses of Legumes}

During the Legume Futures project, non-food uses of legumes were surveyed and catalogued, with a focus on bioenergy and phytoremediation (Stoddard, 2013). 


\section{Bioenergy}

Legumes have a potential role in bioenergy cropping as they reduce reliance on synthetic fertilizer and thus fossil fuel energy, with associated reductions in GHG emissions.

First-generation biofuels are made using simple technologies in order to replace fossil fuels. Legume starch can be converted to bioethanol in the same way as cereal starch, but since starchy legumes generally yield much less than cereals and their starch content is lower, it is highly unlikely that this will ever be economic or sustainable. An early life-cycle analysis of bioenergy production showed that the BNF capacity of soybean gave it a significant advantage over other oilseeds (Hill et al., 2006), but, given the value of soy for food and feed, it is unlikely to ever be grown primarily for energy.

Intercropping bioenergy grasses with legumes can reduce $\mathrm{N}$ fertilizer requirements. In North America, switchgrass (Panicum virgatum L.) yield was not significantly affected by selected legume intercrops, particularly lucerne where soil fertility was low, but $\mathrm{N}$ fertilization was greatly reduced or eliminated (Wang et al., 2010; Butler et al., 2013). Comparable datasets from Europe are scarce, but at high latitudes, the $\mathrm{N}$ fertilization requirement of reed canary grass (Phalaris arundinacea L.) can be reduced by mixed cropping with Galega orientalis Lam. with a mild reduction in yield (Epie et al., 2015). Use of BNF in this way generally reduces nitrous oxide $\left(\mathrm{N}_{2} \mathrm{O}\right)$ emission, contributing to GHG mitigation.

Biorefining offers another way of combining feed and bioenergy production (Jensen et al., 2012). Leaves or leaf protein of lucerne, clover-grass or clover-cereal mixtures can be used for livestock feed and the lignified stems as feedstock for either biofuel or biodegradable plastics (Thomsen and Hauggaard-Nielsen, 2008; González-García et al., 2010; Kamm et al., 2010).

\section{Phytoremediation}

Phytoremediation, or plant-based bioremediation, is a way of using contaminated ground for the production of bioenergy or other industrial products, when growing food or feed is considered inappropriate.

Petroleum oil raises the carbon-to-nitrogen ratio of soil, so the BNF capacity of legumes is a valuable attribute. It also generally includes polycyclic aromatic hydrocarbons (PAHs) that are very toxic and durable, but poorly mobile. Plants have little direct effect on the degradation of petroleum residues; rather, their associated rhizosphere microbes are responsible. Thus in pot experiments, G. orientalis inoculated with Rhizobium galegae promoted oil degradation (Jussila et al., 2006; Kaksonen et al., 2006), but in field experiments there was little difference between galega, brome grass, their mixture, and bare fallow on the rate of oil degradation (Yan et al., 2015).

Sunn hemp (Crotalaria juncea L.) produces long fibres that can be used in similar ways to hemp or jute (Ingle and Doke, 2006), along with pyrrolizidine alkaloids that can bioremediate nematode-infested soils, making it a potentially valuable multi-purpose crop. Field experiments in many warm climates 
have demonstrated the resistance of Crotalaria species to root-knot, root-lesion and other nematodes that parasitize crop plants. Laboratory studies have shown that the alkaloids from sunn hemp species paralyse some nematodes and arrest the development of others (Subramaniyan and Vadivelu, 1990; Jourand et al., 2004; Curto et al., 2015). Sunn hemp can be used as a green manure to control nematodes in field (Curto et al., 2015) and greenhouse (Lajudie et al., in preparation, reported by Stoddard, 2013) production of vegetables.

\section{Legumes in Crop Rotations}

Grain legumes are usually handled as components of crop rotations or sequences rather than as continuous monocultures, because they are just as susceptible to the build-up of soil-borne pathogens and pests as any other arable species. In order to optimize management of pests, weeds and diseases, and to exploit nutrient availability through the soil profile, crop rotations or sequences should incorporate species with different life cycles, growth habits, root architectures and pest spectra (Cook, 2013; Garrison et al., 2014; Reckling et al., 2016a). Rotations are widely understood to improve soil structure, permeability, microbial activity, water storage capacity, organic matter content and resistance to erosion, thus increasing crop yields and sustainability of production systems (Bullock, 1992; Karlen et al., 1994). Both BNF (Knight, 2012) and soil microbial function (Lupwayi et al., 2012) are affected by the frequency of grain legume production. It is usually necessary to inoculate the legume with an appropriate strain of Rhizobium if it is to be sown where it or a related species has not been produced within the previous 5 years, and this inoculation often results in improved legume yields and contributions to soil fertility (Denton et al., 2013). Low soil pH reduces the survival time of rhizobia when no legume host is present (Carter et al., 1995).

A legume influences following crops through a set of 'break-crop', 'nitrogen' and 'legume-specific' effects (Chalk, 1998; Peoples et al., 2009). The breakcrop effect occurs when a cropping sequence lacking diversity, such as the continuous production of small-grain cereals (wheat and barley) typical of most of Europe, is 'broken' by a broadleaved crop or a ley (Robson et al., 2002). The most important part of the effect is the reduction in soil-borne diseases of cereals (Kirkegaard et al., 2008), while other components include the removal of hosts of other pests and the opportunity to use alternative methods and agrochemicals for pest, pathogen and weed reduction (Prew and Dyke, 1979; Stevenson and van Kessel, 1997) and improvements in soil structure (Chan and Heenan, 1996). The nitrogen effect is the release of biologically fixed $\mathrm{N}$ from legume residues, the rate of which is affected by their relatively low C:N ratio, and the impact on the following crop is clearer in sandy than loamy soils (Jensen et al., 2004). The key part of the legume-specific effect is the enhanced growth of plant growth-promoting bacteria (Lugtenberg and Kamilova, 2009), particularly hydrogen-fixing bacteria (Maimaiti et al., 2007), contributing to the improved growth of the following crops such as broccoli after narrow-leafed lupin (Thorup-Kristensen, 1993). The taproot architecture and coarse lateral roots of grain legumes, in contrast to the fine network of cereal roots, assist water infiltration and form channels followed 
by the roots of the subsequent crop, but may also affect leaching (Dunbabin et al., 2003; Neumann et al., 2011). The N content of the legume residues influences the potential for nitrate leaching and $\mathrm{N}_{2} \mathrm{O}$ emissions (Pappa et al., 2011), increasing the value of an N-retaining cover crop, particularly when the following crop is spring sown, leaving a winter fallow (Tuulos et al., 2014). When used as a cover crop, a grain legume can supply $\mathrm{N}$ to the following crop while protecting the bare soil, and mixtures of legumes with other crops further reduce leaching potential (Tosti et al., 2014), with vetches being the most cost-effective (Büchi et al., 2015). $\mathrm{N}$ and phosphorus losses, and ways to limit them, are covered in greater detail in Chapter 3, this volume. The impacts of legumes on biodiversity are reviewed by Everwand et al. (Chapter 4) in this volume.

\section{Current Perspectives on Legume Production}

Within the Legume Futures project we carried out a set of 'case studies', in the sociological sense of the term, in which experts were asked about their knowledge and opinions on various legume-related issues. In Table 1.1, we summarize the opportunities and the challenges for the four main agroclimatic regions (Metzger et al., 2005) as identified by project partners and their local colleagues. Although there were clear regional differences in species grown and agronomic constraints, there were common features as well. A need for economic and environmental evaluation of legume impacts was widely seen. Novel food uses and other innovations could increase demand, which it was hoped would lead to increased profitability. All regions needed better cultivars with higher yield, greater stress resistance and improved quality.

We drew on a network of field research sites across a wide range of agricultural regions of Europe, where legumes had been used in cropping system studies. The network was carefully selected to cover a wide variety of agroeconomic and pedo-climatic zones across Europe, and also covers a range of different uses. By utilizing existing experiments the project aimed to achieve a broad overview of contrasting farming systems with the project resources used to derive additional benefits from their networking. The coverage extended from Jokioinen, Finland in the north $\left(60.81^{\circ} \mathrm{N} 23.49^{\circ} \mathrm{E}\right)$ to Fundulea, Romania in the east $\left(44.46^{\circ} \mathrm{N}\right.$ $\left.26.51^{\circ} \mathrm{E}\right)$, Córdoba, Spain in the south $\left(37.46^{\circ} \mathrm{N} 4.31^{\circ} \mathrm{W}\right)$ and Solohead, Ireland in the west $\left(52.51^{\circ} \mathrm{N} 8.21^{\circ} \mathrm{W}\right)$. Each field site tested certain environmental impacts, and in some cases provided many decades of data (Table 1.2). Five of these locations were used as test sites for examining potential crop rotations and their environmental impacts: (i) the Leibniz Centre for Agricultural Landscape Research (ZALF) Brandenburg; (ii) the Swedish University of Agricultural Sciences (SLU) Skåne; (iii) Scotland's Rural College (SRUC) Edinburgh; (iv) Fundulea; and (v) Reggio Calabria.

It became clear during the project that the assessment of a legume crop in isolation was not enough. The environmental impacts of legume crops are felt over more than one season and beyond the farm gate, so their economic impacts extend in comparable ways. For these reasons, a multi-criteria assessment framework was developed on two sites, integrating leaching potential and GHG emission 
Table 1.1. Expert opinions from the panel of Legume Futures specialists on the attributes and potentials of grain legumes in the four mega-climatic regions of Europe.

\begin{tabular}{|c|c|c|c|c|}
\hline & Atlantic & Continental-Pannonian & Mediterranean & Boreal-Nemoral \\
\hline Main grain legumes & Pea, faba bean & $\begin{array}{l}\text { Pea, faba bean, soybean, } \\
\text { lupin, lentil }\end{array}$ & $\begin{array}{l}\text { Wide range, including } \\
\text { chickpea }\end{array}$ & Pea, faba bean \\
\hline $\begin{array}{l}\text { Major agronomic } \\
\text { constraints }\end{array}$ & $\begin{array}{l}\text { Weed control in grain } \\
\text { legumes }\end{array}$ & $\begin{array}{l}\text { Yield stability in grain } \\
\text { legumes, soil-borne and } \\
\text { other diseases, weed } \\
\text { infestation, drought }\end{array}$ & $\begin{array}{l}\text { Weed control, yield } \\
\text { stability }\end{array}$ & $\begin{array}{l}\text { Disease (e.g. aphanomyces, } \\
\text { chocolate spot, grey mould), } \\
\text { competitiveness against weeds } \\
\text { (especially in organic systems), } \\
\text { yield stability }\end{array}$ \\
\hline $\begin{array}{l}\text { Supply chain } \\
\text { constraints }\end{array}$ & $\begin{array}{l}\text { Feed quality, lack of } \\
\text { processing facilities }\end{array}$ & $\begin{array}{l}\text { Varying prices and qualities } \\
\text { of legume fodder } \\
\text { compounds results in low } \\
\text { market demands }\end{array}$ & No answer & $\begin{array}{l}\text { Markets needed to encourage } \\
\text { farmers to grow grain legumes, } \\
\text { companies have difficulty } \\
\text { handling small volumes of } \\
\text { variable quality }\end{array}$ \\
\hline \multirow[t]{2}{*}{ Policy needs } & $\begin{array}{l}\text { Economic and } \\
\text { environmental } \\
\text { evaluation }\end{array}$ & $\begin{array}{l}\text { Economic and } \\
\text { environmental evaluation }\end{array}$ & $\begin{array}{l}\text { Economic and } \\
\text { environmental } \\
\text { evaluation }\end{array}$ & No answer \\
\hline & & & & Continued \\
\hline
\end{tabular}


Table 1.1. Continued.

\begin{tabular}{|c|c|c|c|c|}
\hline & Atlantic & Continental-Pannonian & Mediterranean & Boreal-Nemoral \\
\hline Other needs & Consumer education & No answer & Better extension service & No answer \\
\hline $\begin{array}{l}\text { Growth areas/ } \\
\text { opportunities }\end{array}$ & $\begin{array}{l}\text { Beans for feed (fish } \\
\text { and monogastrics), } \\
\text { increased use } \\
\text { of white clover } \\
\text { in pastures to } \\
\text { reduce fertilizer } \mathrm{N} \\
\text { use, legumes for } \\
\text { perennial systems } \\
\text { (e.g. agroforestry) }\end{array}$ & $\begin{array}{l}\text { Demand for GM-free food, } \\
\text { functional foods and } \\
\text { locally produced food/feed }\end{array}$ & $\begin{array}{l}\text { Legumes for food, } \\
\text { green manures } \\
\text { for soil fertility, } \\
\text { intercropping for } \\
\text { forage and grain, use } \\
\text { of intercrop residues } \\
\text { for biofuel production, } \\
\text { engagement of } \\
\text { seed companies in } \\
\text { promotion }\end{array}$ & $\begin{array}{l}\text { Novel food uses, lucerne for } \\
\text { restoring compacted soils, } \\
\text { growth in organic production } \\
\text { will drive legume production }\end{array}$ \\
\hline Breeding demand & $\begin{array}{l}\text { Early maturing winter } \\
\text { beans, cultivars } \\
\text { compatible with } \\
\text { undersowing or } \\
\text { intercropping with } \\
\text { cereals }\end{array}$ & $\begin{array}{l}\text { Winter hardiness, disease } \\
\text { resistance, low contents of } \\
\text { antinutritional compounds, } \\
\text { peas with stiffer straw, } \\
\text { autumn-sown cultivars of } \\
\text { grain legumes }\end{array}$ & $\begin{array}{l}\text { Adapted cultivars } \\
\text { for winter sowing, } \\
\text { many landraces } \\
\text { used in some } \\
\text { countries, cultivars for } \\
\text { intercropping }\end{array}$ & $\begin{array}{l}\text { Earlier maturity especially in } \\
\text { beans, better feed quality, } \\
\text { disease resistance, processing } \\
\text { to improve feed quality }\end{array}$ \\
\hline
\end{tabular}

${ }^{\mathrm{a}} \mathrm{GM}$, Genetically modified. 
Table 1.2. Field experiments used in the Legume Futures project.

\begin{tabular}{|c|c|c|c|}
\hline Country & Institution ${ }^{a}$ & Primary purpose of the field experiment ${ }^{b}$ & Environmental impacts investigated \\
\hline Denmark & Aarhus University & $\begin{array}{l}\text { Organic/conventional cropping comparison including } \\
\text { dairy, mixed cropping, rotations, assessment of } \\
\text { leaching, GHG and } \mathrm{NH}_{3} \text { emissions (three sites) }\end{array}$ & $\mathrm{N}$ cycling \\
\hline Finland & University of Helsinki & Rotations, crop diversity, intercropping & Bioremediation, multifunctionality \\
\hline Finland & LUKE & $\begin{array}{l}\text { Organic/conventional cropping comparison with and without } \\
\text { livestock, green manure, leaching }\end{array}$ & Multifunctionality \\
\hline France & CIRAD & Green manure in greenhouse vegetable production & Biological control of nematodes \\
\hline Germany & ZALF & Organic dairy farming & Weed reduction, nutrient dynamics \\
\hline Germany & Von Thünen Institute & $\begin{array}{l}\text { Mixed organic cropping, rotations, whole-crop silage, } \\
\text { leaching assessment }\end{array}$ & N cycling \\
\hline Greece & $\begin{array}{l}\text { Agricultural University } \\
\text { of Athens }\end{array}$ & Organic/conventional cropping comparison & Salinity management \\
\hline Ireland & $\begin{array}{l}\text { Teagasc and Trinity } \\
\text { College Dublin }\end{array}$ & Mineral N vs BNF, $\mathrm{N}$ flow, life cycle assessment, leaching & $\begin{array}{l}\text { Biodiversity, disease cycles, } \mathrm{N} \\
\text { cycling }\end{array}$ \\
\hline Italy & $\begin{array}{l}\text { Università Mediterranea } \\
\text { di Reggio Calabria }\end{array}$ & Legume-cereal intercropping & $\begin{array}{l}\mathrm{N} \text { cycling, biodiversity, } \\
\text { multifunctionality }\end{array}$ \\
\hline Poland & IUNG-PIB & $\begin{array}{l}\text { Organic/conventional ('integrated') cropping comparison, } \\
\text { crop rotation }\end{array}$ & N cycling \\
\hline Romania & $\begin{array}{l}\text { Agricultural University of } \\
\text { Romania at Fundulea }\end{array}$ & Organic cropping; cultivars for organic systems & $\mathrm{N}$ cycling, biodiversity \\
\hline Spain & University of Córdoba & Rotations, tillage; broomrape control & $\begin{array}{l}\mathrm{N} \text { cycling, disease cycles, } \mathrm{C} \\
\text { sequestration }\end{array}$ \\
\hline Sweden & SLU & Rotations; non-dairy systems (three sites) & Disease cycles, $\mathrm{N}$ cycling \\
\hline UK & SRUC & $\begin{array}{l}\text { 1: Organic rotation; stocked and stockless systems, GHG } \\
\text { exchanges; 2: Synthetic nitrogen sources; GHG exchange }\end{array}$ & Nutrient dynamics \\
\hline UK & James Hutton Institute & $\begin{array}{l}\text { Stockless, arable rotations, conventional and alternative } \\
\text { strategies for nutrient supply }\end{array}$ & $\begin{array}{l}\mathrm{N} \text { cycling, biodiversity, disease } \\
\text { cycles, multifunctionality }\end{array}$ \\
\hline
\end{tabular}

${ }^{a}$ CIRAD, Agricultural Research Centre for International Development; IUNG-PIB, Institute of Soil Science and Plant Cultivation; LUKE, Natural Resources Institute; SLU, Swedish University of Agricultural Sciences; SRUC, Scotland's Rural College; ZALF, Leibniz Centre for Agricultural Landscape Research. ${ }^{\mathrm{b} B N F}$, Biological nitrogen fixation; $\mathrm{C}$, carbon; $\mathrm{GHG}$, greenhouse gas; $\mathrm{N}$, nitrogen; $\mathrm{NH}_{3}$, ammonia. 
risk along with the gross margins of crop production including pre-crop effects in a modified rotation generator (Reckling et al., 2016a) and extended to five sites (Reckling et al., 2016b). On average, $\mathrm{N}_{2} \mathrm{O}$ emission was reduced in legume-supported systems by 18\% (arable) and 33\% (forage), while nitrate leaching potential was reduced by $24 \%$ and $38 \%$, respectively). Gross margins were improved by legumes in all three forage test cases, but in only two of the five arable test cases (Reckling et al., 2016b). Novel rotations were generated that provided higher potential gross margins than the current general practice. Related economic aspects of using legumes in European agricultural systems are covered by Preissel et al. (Chapter 13, this volume) and the attendant policy issues by Kuhlman et al. (Chapter 14, this volume) in this volume.

\section{Conclusion}

Grain and forage legumes have considerable potential in European cropping systems. When used wisely and produced with appropriate attention to their requirements, they can improve the environmental impact of agriculture and farm incomes. This book presents chapters on the complete legume chain, from the production of forage and grain species, to their impacts on the environment, the economy and the human diet. The perspective is European throughout, with overseas data included where appropriate.

\section{References}

Anil, L., Park, J., Phipps, R.H. and Miller, F.A. (1998) Temperate intercropping of cereals for forage: a review of the potential for growth and utilization with particular reference to the UK. Grass and Forage Science 53, 301-307.

Ayadi, F.Y., Rosentrater, K.A. and Muthukumarappan, K. (2012) Alternative protein sources for aquaculture feeds. Journal of Aquaculture Feed Science and Nutrition 4, 1-26.

Azuhnwi, B.N., Hertzberg, H., Arrigo, Y., Gutzwiller, A., Hess, H.D., Mueller-Harvey, I., Torgerson, P.R., Kreuzer, M. and Dohme-Meier, F. (2013) Investigation of sainfoin (Onobrychis viciifolia) cultivar differences on nitrogen balance and fecal egg count in artificially infected lambs. Journal of Animal Science 91, 2343-2354.

Baddeley, J.A., Jones, S., Topp, C.F.E., Watson, C.A., Helming, J. and Stoddard, F.L. (2013) Biological nitrogen fixation (BNF) by legume crops in Europe. Legume Futures Report 1.5. Available at: www.legumefutures.de (accessed 30 March 2016).

Beauchemin, K.A., Kreuzer, M., O'Mara, F. and McAllister, T.A. (2008) Nutritional management for enteric methane abatement: a review. Australian Journal of Experimental Agriculture 48, 21-27.

Bedoussac, L., Journet, E.-P., Hauggaard-Nielsen, H., Naudin, C., Corre-Hellou, G., Jensen, E.S., Prieur, L. and Justes, E. (2015) Ecological principles underlying the increase of productivity achieved by cereal-grain legume intercrops in organic farming. A review. Agronomy for Sustainable Development 35, 911.

Bertoglio, J.C., Calvo, M.A., Hancke, J.L., Burgos, R.A., Riva, A., Morazzoni, P., Ponzone, C., Magni, C. and Duranti, M. (2011) Hypoglycemic effect of lupin seed $\gamma$-conglutin in experimental animals and healthy human subjects. Fitoterapia 82, 933-938. 
Büchi, L., Gebhard, C.A., Liebish, F., Sinaj, S., Ramseier, H. and Charles, R. (2015) Accumulation of biologically fixed nitrogen by legumes cultivated as cover crops in Switzerland. Plant and Soil 393, 163-175.

Bullock, D.G. (1992) Crop rotation. Critical Reviews in Plant Science 11, 309-326.

Butler, T.J., Muir, J.P., Huo, C. and Guretzky, J.A. (2013) Switchgrass biomass and nitrogen yield with overseeded cool-season forages in the southern Great Plains. Bioenergy Research 6, 44-52.

Campos-Vega, R., Loarca-Pina, G. and Oomah, B.D. (2010) Minor components of pulses and their potential impact on human health. Food Research International 43, 461-482.

Carlsson, G. and Huss-Danell, K. (2003) Nitrogen fixation in perennial forage legumes in the field. Plant and Soil 253, 353-372.

Carter, J.M., Tieman, J.S. and Gibson, A.H. (1995) Competitiveness and persistence of strains of rhizobia for faba bean in acid and alkaline soils. Soil Biology and Biochemistry 27, 617-623.

Cernay, C., Ben-Ari, T., Pelzer, E., Meynard, J.-M. and Makowski, D. (2015) Estimating variability in grain legume yields across Europe and the Americas. Scientific Reports 5, 11171.

Chalk, P.M. (1998) Dynamics of biologically fixed $\mathrm{N}$ in legume-cereal rotations: a review. Australian Journal of Agricultural Research 49, 303-316.

Chan, K.Y. and Heenan, D.P. (1996) The influence of crop rotation on soil structure and soil physical properties under conventional tillage. Soil and Tillage Research 37, 113-125.

Cook, D., Grum, D.S., Gardner, D.R., Welch, K.D. and Pfister, J.A. (2013) Influence of endophyte genotype on swainsonine concentrations in Oxytropis sericea. Toxicon 61, 105-111.

Cornara, L., Xiao, J.B. and Burlando, B. (2015) Therapeutic potential of temperate forage legumes: a review. Critical Reviews in Food Science and Nutrition 56, S149-S161.

Crépon, K. (2006) Nutritional value of legumes (pea and faba bean) and economics of their use. In: Garnsworthy, P.C. and Wiseman, J. (eds) Recent Advances in Animal Nutrition. Nottingham University Press, Nottingham, UK, pp. 331-366.

Curto, G., Dallavalle, E., Santi, R., Casadei, N., D’Avino, L. and Lazzeri, L. (2015) The potential of Crotalaria juncea L. as a summer green manure crop in comparison to Brassicaceae catch crops for management of Meloidogyne incognita in the Mediterranean area. European Journal of Plant Pathology 142, 829-841.

Dawson, L.E.R. (2012) The effect of inclusion of lupins/triticale whole crop silage in the diet of winter finishing beef cattle on their performance and meat quality at two levels of concentrates. Animal Feed Science and Techology 171, 75-84.

Day, L. (2013) Proteins from land plants - potential resources for human nutrition and food security. Trends in Food Science and Technology 32, 25-42.

Denton, M.D., Pearce, D.J. and Peoples, M.B. (2013) Nitrogen contributions from faba bean (Vicia faba L.) reliant on soil rhizobia or inoculation. Plant Soil 365, 363-374.

Diaz, D., Morlacchini, M., Masoero, F., Moschini, M., Fusconi, G. and Piva, G. (2006) Pea seeds (Pisum sativum), faba beans (Vicia faba var. minor) and lupin seeds (Lupinus albus var. multitalia) as protein sources in broiler diets: effect of extrusion on growth performance. Italian Journal of Animal Science 5, 43-53.

Dunbabin, V., Diggle, A. and Rengel, Z. (2003) Is there an optimal root architecture for nitrate capture in leaching environments? Plant, Cell and Environment 26, 835-844.

Epie, K.E., Saikkonen, L., Santanen, A., Jaakkola, S., Mäkelä, P., Simojoki, A. and Stoddard, F.L. (2015) Nitrous oxide emissions from perennial grass-legume intercrop for bioenergy use. Nutrient Cycling in Agroecosystems 101, 211-222.

Eurostat (2016) Eurostat. European Commission, Brussels. Available at: http://ec.europa.eu/ eurostat (accessed 30 April 2016).

FAOSTAT (2015) Statistics Database of the Food and Agriculture Organization of the United Nations. Food and Agriculture Organization of the United Nations, Rome. Available at: http://faostat3.fao.org/home/E (accessed 2 February 2016). 
Food and Agriculture Organization of the United Nations (FAO) (2004) Protein sources for the animal feed industry. In: Proceedings of An Expert Consultation and Workshop, Bangkok, 29 April-3 May 2002. FAO, Rome, pp. ix-xxv.

Garrison, A.J., Miller, A.D., Ryan, M.R., Roxburgh, S.H. and Shea, K. (2014) Stacked crop rotations exploit weed-weed competition for sustainable weed management. Weed Science 62, 166-176.

Gatel, F. (1994) Protein quality of legume seeds for non-ruminant animals: a literature review. Animal Feed Science and Technology 45, 317-348.

Girard, M., Dohme-Meier, F., Silacci, P., Ampuero Kragten, S., Kreuzer, M. and Bee, G. (2015) Forage legumes rich in condensed tannins may increase $n-3$ fatty acid levels and sensory quality of lamb meat. Journal of the Science of Food and Agriculture 96, 1923-1933.

Glencross, B., Hawkins, W., Evans, D., Rutherford, N., Dods, K., McCafferty, P. and Sipsas, S. (2008) Evaluation of the influence of Lupinus angustifolius kernel meal on dietary nutrient and energy utilization efficiency by rainbow trout (Oncorhynchus mykiss). Aquaculture Nutrition 14, 129-138.

Gomes, E.F., Rema, P. and Kaushik, S.J. (1995) Replacement of fish meal by plant proteins in the diet of rainbow trout (Oncorhynchus mykiss): digestibility and growth performance. Aquaculture 130, 177-186.

González-García, S., Moreira, M.T. and Feijoo, G. (2010) Environmental performance of lignocellulosic bioethanol production from alfalfa stems. Biofuels, Bioproducts and Biorefining 4, 118-131.

Harland, J.I. and Haffner, T.A. (2008) Systematic review, meta-analysis and regression of randomised controlled trials reporting an association between an intake of circa $25 \mathrm{~g}$ soya protein per day and blood cholesterol. Atherosclerosis 200, 13-27.

Hasha, G. (2002) Livestock feeding and feed imports in the European Union - A decade of change. FDS-0602-01. Electronic Outlook Report from the Economic Research Service, Economic Research Service (ERS), United States Department of Agriculture (USDA), 28 pp. Available at: http://www.ers.usda.gov/media/1725328/fds060201.pdf (accessed 30 September 2016).

Herman, E.M. and Schmidt, M.A. (2016) The potential for engineering enhanced functional-feed soybeans for sustainable aquaculture feed. Frontiers in Plant Science 7, 440.

Hill, J., Nelson, E., Tilman, D., Polasky, S. and Tiffany, D. (2006) Environmental, economic, and energetic costs and benefits of biodiesel and ethanol biofuels. Proceedings of the National Academy of Sciences of the USA 103, 11207-11211.

Hoste, R. and Bolhuis, J. (2010) Soya Consumption in the Netherlands. Landbouw-Economisch Institut (LEI) Report 2010-059. LEI, The Hague, the Netherlands.

Huisman, J. and Jansman, A.J.M. (1991) Dietary effect and some analytical aspects of antinutritional factors in peas (Pisum sativum), common beans (Phaseolus vulgaris) and soybeans (Glycine $\max$ L.) in monogastric farm animals: a literature review. Nutrition Abstracts and Reviews (Series B) 60, 901-921.

Humer, E. and Schedle, K. (2016) Fermentation of food and feed: a technology for efficient utilization of macro and trace elements in monogastrics. Journal of Trace Elements in Medicine and Biology 37, 69-77.

Humphreys, J., O'Connell, K. and Casey, I.A. (2008) Nitrogen flows and balances in four grassland-based systems of dairy production on a clay-loam soil in a moist maritime climate. Grass and Forage Science 63, 467-480.

Ingle, N.P. and Doke, S.S. (2006) Analysis of sunnhemp fibers processed using jute spinning system. Industrial Crops and Products 23, 235-243.

Jensen, C.R., Joernsgaard, B., Andersen, M.N., Christiansen, J.L., Mogensen, V.O., Friis, P. and Petersen, C.T. (2004) The effect of lupins as compared with peas and oats on the yield of the subsequent winter barley crop. European Journal of Agronomy 20, 405-418. 
Jensen, E.S., Peoples, M.B., Boddey, R.M., Gresshoff, P.M., Hauggaard-Nielsen, H., Alves, B.J.R. and Morrison, M.J. (2012) Legumes for mitigation of climate change and the provision of feedstock for biofuels and biorefineries. A review. Agronomy for Sustainable Development 32, 329-364.

Jezierny, D., Mosenthin, R. and Bauer, E. (2010) The use of grain legumes as a protein source in pig nutrition: a review. Animal Feed Science and Technology 157, 111-128.

Jourand, P., Rapior, S., Fargette, M. and Mateille, T. (2004) Nematostatic activity of aqueous extracts of West African Crotalaria species. Nematology 6, 765-771.

Jussila, M.M., Jurgens, G., Lindström, K. and Suominen, L. (2006) Genetic diversity of culturable bacteria in oil-contaminated rhizosphere of Galega orientalis. Environmental Pollution 139, 244-257.

Kaksonen, A.H., Jussila, M.M., Lindström, K. and Suominen, L. (2006) Rhizosphere effect of Galega orientalis in oil-contaminated soil. Soil Biology and Biochemistry 38, 817-827.

Kamm, B., Hille, C., Schönicke, P. and Dautzenberg, G. (2010) Green biorefinery demonstration plant in Havelland (Germany). Biofuels, Bioproducts and Biorefining 4, 253-262.

Karlen, D.L., Varvel, G.E., Bullock, D.G. and Cruse, R.M. (1994) Crop rotations for the 21 st century. Advances in Agronomy 53, 1-45.

Kirkegaard, J.A., Christen, O., Krupinsky, J. and Layzell, D. (2008) Break crop benefits in temperate wheat production. Field Crops Research 107, 185-195.

Knight, J D. (2012) Frequency of field pea in rotations impacts biological nitrogen fixation. Canadian Journal of Plant Science 92, 1005-1011.

Krogdahl, Å., Penn, M.H., Thorsen, J., Refstie, S. and Bakke, A.M. (2010) Important antinutrients in plant feedstuffs for aquaculture: an update on recent findings regarding responses in salmonids. Aquaculture Research 41, 333-344.

Lassaletta, L., Billen, G., Romero, E., Garnier, J. and Aguilera, E. (2014) How changes in diet and trade patterns have shaped the $\mathrm{N}$ cycle at the national scale: Spain (1961-2009). Regional Environmental Change 14, 785-797.

Laudadio, V. and Tufarelli, V. (2010) Treated fava bean (Vicia faba var. minor) as substitute for soybean meal in diet of early phase laying hens: egg-laying performance and egg quality. Poultry Science 89, 2299-2303.

Lugtenberg, B. and Kamilova, F. (2009) Plant-growth-promoting rhizobacteria. Annual Review of Microbiology 63, 541-556.

Lupwayi, N.Z., Lafond, G.P., May, W.E., Holzapfel, C.B. and Lemke, R.L. (2012) Intensification of field pea production: impact on soil microbiology. Agronomy Journal 104, 1189-1196.

Maimaiti, J., Zhang,Y., Yang, J., Cen, Y.-P., Layzell, D.B., Peoples, M. and Dong, Z. (2007) Isolation and characterization of hydrogen-oxidizing bacteria induced following exposure of soil to hydrogen gas and their impact on plant growth. Environmental Microbiology 9, 435-444.

Malézieux, E., Crozat, Y., Dupraz, C., Laurans, M., Makowski, D., Ozier-Lafontaine, H., Rapidel, B., deTourdonnet, S. and Valantin-Morison, M. (2009) Mixing plant species in cropping systems: concepts, tools and models. A review. Agronomy for Sustainable Development 29, 43-62.

McCrory, M.A., Hamaker, B.R., Lovejoy, J.C. and Eichelsdoerffer, P.E. (2010) Pulse consumption, satiety and weight management. Advances in Nutrition 1, 17-30.

Metzger, M.J., Bunce, R.G.H, Jongman, R.H.G, Mucher, C.A. and Watkins, J.W. (2005) A climatic stratification of the environment of Europe. Global Ecology and Biogeography 14, 549-563.

Neumann, A., Torstensson, G. and Aronsson, H. (2011) Losses of nitrogen and phosphorus via the drainage system from organic crop rotations with and without livestock on a clay soil in southwest Sweden. Organic Agriculture 1, 217-229.

O'Mara, F. (2008) Country Pasture/Forage Resource Profile for Ireland. Food and Agriculture Organization of the United Nations (FAO), Rome. Available at: http://www.fao.org/ag/AGP/ AGPC/doc/Counprof/PDF\%20files/Ireland.pdf (accessed 26 February 2013). 
Palander, S., Laurinen, P., Perttilä, S., Valaja, J. and Partanen, K. (2006) Protein and amino acid digestibility and metabolizable energy value of pea (Pisum sativum), faba bean (Vicia faba) and lupin (Lupinus angustifolius) seeds for turkeys of different age. Animal Feed Science and Technology 127, 89-100.

Pappa, V.A., Rees, R.M., Walker, R.L., Baddeley, J.A. and Watson, C.A. (2011) Nitrous oxide emissions and nitrate leaching in an arable rotation resulting from the presence of an intercrop. Agriculture, Ecosystems and Environment 141, 153-161.

Pelletier, N. and Tyedmers, P. (2010) Forecasting potential global environmental costs of livestock production 2000-2050. Proceedings of the National Academy of Sciences of the USA 107, 18371-18374.

Peoples, M.B., Brockwell, J., Herridge, D.F., Rochester, I.J., Alves, B.J.R., Urquiaga, S., Boddey, R.M., Dakora, F.D., Bhattarai, S., Maskey, S.L., Sampet, C., Rerkasem, B., Khan, D.F., Hauggaard-Nielsen, H. and Jensen, E.S. (2009) The contributions of nitrogenfixing crop legumes to the productivity of agricultural systems. Symbiosis 48, 1-17.

Peyraud, J.L., Le Gall, A. and Lüscher, A. (2009) Potential food production from forage legume-based systems in Europe: an overview. Irish Journal of Agricultural and Food Research 48, 115-135.

Phelan, P., Moloney, A.P., McGeough, E.J., Humphreys, J., Bertilsson, J., O'Riordan, E.G. and O'Kiely, P. (2015) Forage legumes for grazing and conserving in ruminant production systems. Critical Reviews in Plant Sciences 34, 281-326.

Prew, R.D. and Dyke, G.V. (1979) Experiments comparing 'break crops' as a preparation for winter wheat followed by spring barley. Journal of Agricultural Science, Cambridge 92, 189-201.

Public Health England (2016) The Eatwell Guide. Department of Health in association with the Welsh Assembly Government, the Scottish Government and the Food Standards Agency in Northern Ireland, London.

Reckling, M., Hecker, J.-M., Bergkvist, G., Watson, C.A., Zander, P., Schläfke, N., Stoddard, F.L., Eory, V., Topp, C.F.E., Maire, J. and Bachinger, J. (2016a) A cropping assessment framework - evaluating effects of introducing legumes into crop rotations. European Journal of Agronomy 76, 186-197.

Reckling, M., Bergkvist, G., Watson, C.A., Stoddard, F.L., Zander, P.M., Walker, R., Pristeri, A., Toncea, I. and Bachinger, J. (2016b) Trade-offs between economic and environmental impacts of introducing legumes into cropping systems. Frontiers in Plant Science 7, 669.

Renna, M., Cornale, P., Lussiana, C., Malfatto, V., Fortina, R., Mimosi, A. and Battaglini, L.M. (2012) Use of Pisum sativum (L.) as alternative protein resource in diets for dairy sheep: effects on milk yield, gross composition and fatty acid profile. Small Ruminant Research 102, 142-150.

Robson, M.C., Fowler, S.M., Lampkin, N.H., Leifert, C., Leitch, M., Robinson, D., Watson, C.A. and Litterick, A.M. (2002) The agronomic and economic potential of break crops for ley/arable rotations in temperate organic agriculture. Advances in Agronomy 77, 369-427.

Scalbert, A., Manach, C., Morand, C., Remesy, C. and Jimenez, L. (2005) Dietary polyphenols and the prevention of diseases. Critical Reviews in Food Science 45, 287-306.

Schreurs, N.M., Mcnabb, W.C., Tavendale, M.H., Lane, G.A., Barry, T.N., Cummings, T., Fraser, K., López-Villalobos, N. and Rámirez-Restrepo, C.A. (2007) Skatole and indole concentration and the odour of fat from lambs that had grazed perennial ryegrass/white clover pasture or Lotus corniculatus. Animal Feed Science and Technology 138, 254-271.

Sirtori, C.R., Galli, C., Anderson, J.W. and Arnoldi, A. (2009) Nutritional and nutraceutical approaches to dyslipidemia and atherosclerosis prevention: focus on dietary proteins. Atherosclerosis 203, 8-17.

Sirtori, C.R., Triolo, M., Bosisio, R., Bondioli, A., Calabresi, L., De Vergori, V., Gomaraschi, M., Mombelli, G., Pazzucconi, F., Zacherl, C. and Arnoldi, A. (2012) Hypocholesterolaemic effects of lupin protein and pea protein/fibre combinations in moderately hypercholesterolaemic individuals. British Journal of Nutrition 107, 1176-1183.

Steinshamn, H. (2010) Effect of forage legumes on feed intake, milk production and milk quality - a review. Animal Science Papers and Reports 28, 195-206. 
Stevenson, F.C. and van Kessel, C. (1997) Nitrogen contribution of pea residue in a hummocky terrain. Soil Science Society of America Journal 61, 494-503.

Stoddard, F.L. (2013) Novel feed and non-food uses of legumes. Legume Futures Report 1.3. Available at: www.legumefutures.de (accessed 30 September 2016).

Stoddard, F.L., Hovinen, S., Kontturi, M., Lindström, K. and Nykänen, A. (2009) Legumes in Finnish agriculture: history, present status and future prospects. Agricultural and Food Science 18, 191-205.

Strohle, A., Waldmann, A., Wolters, M. and Hahn, A. (2006) Vegetarian nutrition: preventive potential and possible risks part 1: Plant foods. Wiener Klinische Wochenschrift 118, 580-593.

Subramaniyan, S. and Vadivelu, S. (1990) Effects of Crotalaria spectabilis extracts on Meloidogyne incognita. International Nematology Network Newsletter 7, 8-9.

Tacon, A.G.J., Hasan, M.R. and Metian, M. (2011) Demand and supply of feed ingredients for farmed fish and crustaceans. Trends and prospects. Food and Agriculture Organization of the United Nations (FAO) Fisheries and Aquaculture Technical Paper 564. FAO. Rome.

Thomsen, M.H. and Hauggaard-Nielsen, H. (2008) Sustainable bioethanol production combining biorefinery principles using combined raw materials from wheat undersown with clover-grass. Journal of Industrial Microbiology and Biotechnology 35, 303-311.

Thorup-Kristensen, K. (1993) Root growth of nitrogen catch crops and of a succeeding crop of broccoli. Acta Agriculturae Scandinavica Section B: Soil and Plant Science 43, 58-64.

Tosti, G., Benincasa, P., Farneselli, M., Tei, F. and Guiducci, M. (2014) Barley-hairy vetch mixture as cover crop for green manuring and the mitigation of $\mathrm{N}$ leaching risk. European Journal of Agronomy 54, 34-39.

Trushenski, J.T., Kasper, C.S. and Kohler, C.C. (2006) Challenge and opportunities in finfish nutrition. North American Journal of Aquaculture 68, 122-140.

Tuulos, A., Yli-Halla, M., Stoddard, F.L. and Mäkelä, P.S.A. (2014) Winter turnip rape as a soil $\mathrm{N}$ scavenging catch crop in a cool humid climate. Agronomy for Sustainable Development 35, 359-366.

Valtion Ravitsemusneuvottelukunta (VRN) (2014) Nutrition Recommendations. Available at: http://www.ravitsemusneuvottelukunta.fi/portal/en/nutrition+recommendations/ (accessed 30 March 2016).

Vander Pol, M., Hristov, A.N., Zaman, S. and Delano, N. (2008) Peas can replace soybean meal and corn grain in dairy cow diets. Journal of Dairy Science 91, 698-703.

Vicenti, A., Toteda, F., Di Turi, L., Cocca, C., Perrucci, M., Melodia, L. and Ragni, M. (2009) Use of sweet lupin (Lupinus albus L. var. Multitalia) in feeding for Podolian young bulls and influence on productive performances and meat quality traits. Meat Science 82, 247-251.

Volpelli, L.A., Comellini, M., Masoero, F., Moschini, M., Lo Fiego, D.P. and Scipioni, R. (2010) Faba beans (Vicia faba) in dairy cow diet: effect on milk production and quality. Italian Journal of Animal Science 9, 138-144.

Waghorn, G. (2008) Beneficial and detrimental effects of dietary condensed tannins for sustainable sheep and goat production: progress and challenges. Animal Feed Science and Technology 147, 116-139.

Wang, D., Lebauer, D.S. and Dietze, M.C. (2010) A quantitative review comparing the yield of switchgrass in monocultures and mixtures in relation to climate and management factors. Global Change Biology Bioenergy 2, 16-25.

Westhoek, H., Rood, T., van deBerg, M., Janse, J., Nijdam, D., Reudink, M. and Stehfest, E. (2011) The Protein Puzzle. PBL Netherlands Environmental Assessment Agency: The Hague, the Netherlands.

White, G.A., Smith, L.A., Houdijk, J.G.M., Homer, D., Kyriazakis, I. and Wiseman, J. (2015) Replacement of soya bean meal with peas and faba beans in growing/finishing pig diets: effect on performance, carcass composition and nutrient excretion. Animal Feed Science and Technology 209, 202-210.

Yan, L., Penttinen, P., Simojoki, A., Stoddard, F.L. and Lindström, K. (2015) Perennial crop growth in oil-contaminated soil in a boreal climate. Science of the Total Environment 532, 752-761. 